ISSN 1678-3921

Journal homepage: www.embrapa.br/pab

For manuscript submission and journal contents, access: www.scielo.br/pab

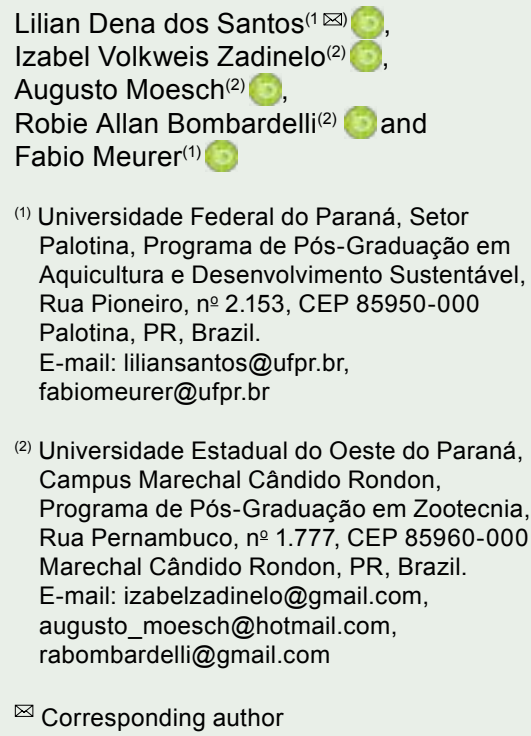

(2) Universidade Estadual do Oeste do Paraná, Campus Marechal Cândido Rondon, Programa de Pós-Graduação em Zootecnia Rua Pernambuco, № 1.777, CEP 85960-000 Marechal Cândido Rondon, PR, Brazil. E-mail: izabelzadinelo@gmail.com, augusto_moesch@hotmail.com, rabombardelli@gmail.com

$\bowtie$ Corresponding author

Received

January 23, 2018

Accepted

April 30, 2019

How to cite

SANTOS, L.D. dos; ZADINELO, I.V.; MOESCH A.; BOMBARDELLI, R.A.; MEURER, F Crude glycerol in diets for Nile tilapia in the fattening stage. Pesquisa Agropecuária Brasileira, v.54, e00460, 2019. DOI: https://doi. org/10.1590/S1678-3921.pab2019.v54.00460.

\section{Crude glycerol in diets for Nile tilapia in the fattening stage}

\begin{abstract}
The objective of this work was to evaluate the use of crude glycerol as an energy source to replace corn, in diets for Nile tilapia (Oreochromis niloticus) in the fattening stage. Two hundred Nile tilapia $(190 \pm 4.5 \mathrm{~g})$ were distributed in 20 tanks, in a completely randomized design. The treatments consisted of crude glycerol at $0,60,120,180$, and $240 \mathrm{~g} \mathrm{~kg}^{-1}$, to replace the dietary levels of corn, in order to maintain a constant digestible energy. Fish productive performance and the chemical composition of the fillet were evaluated. Histological analyses of the hepatopancreas, intestine, and visceral fat were also carried out. Crude glycerol had no effect on the performance parameters; however, it caused a quadratic reduction of visceral fat. There was an increase in the moisture and a decrease in the ether extract of the fillet. A linear effect on the blood glucose levels was verified in fish fed the diet without glycerol, and the peak occurred at $90 \mathrm{~min}$. There were no differences for measurements of intestinal villi height and hepatocyte area. Crude glycerol can replace corn in diets for Nile tilapia in the fattening stage, without adversely affecting fish metabolism, productive performance, or survival.
\end{abstract}

Index terms: Oreochromis niloticus, Zea mays, alternative feed, biofuel, byproduct.

\section{Glicerol bruto em dietas para tilápia- do-nilo na fase de terminação}

Resumo - O objetivo deste trabalho foi avaliar o uso de glicerol bruto como fonte de energia em substituição ao milho, em dietas para tilápia-donilo (Oreochromis niloticus) em fase de engorda. Duzentas tilápias-do-nilo $(190 \pm 4,5 \mathrm{~g})$ foram distribuídas em 20 tanques, em delineamento inteiramente casualizado. Os tratamentos consistiram de 0, 60, 120, 180 e $240 \mathrm{~g} \mathrm{~kg}^{-1} \mathrm{de}$ glicerol bruto, em substituição ao milho na dieta, para manter a energia digestível constante. Foram avaliados o desempenho produtivo dos peixes e a composição química dos filés. Também foram realizadas análises histológicas do hepatopâncreas, do intestino e da gordura visceral. O glicerol bruto não teve efeito sobre os parâmetros de desempenho; no entanto, causou redução quadrática da gordura visceral. Houve aumento da umidade e redução do extrato etéreo dos filés. Verificou-se efeito linear dos níveis de glicose no sangue dos peixes alimentados com a dieta sem glicerol, com pico aos $90 \mathrm{~min}$. Não houve diferenças quanto às medidas referentes à altura das vilosidades intestinais e à área dos hepatócitos. O glicerol bruto pode ser utilizado em substituição ao milho, em dietas para tilápias-do-nilo na fase de engorda, pois não afeta negativamente o metabolismo, o desempenho produtivo ou a sobrevivência dos peixes.

Termos para indexação: Oreochromis niloticus, Zea mays, alimento alternativo, biocombustível, subprodutos. 


\section{Introduction}

Since the late 1980s, capture fisheries production has stagnated, and aquaculture has been responsible for an increased availability of fish for human consumption (FAO, 2018). In 2016, the worldwide production of animal aquaculture reached about 80 million tonnes (FAO, 2018). Tilapia represents $55.4 \%$ of the Brazilian aquaculture production (PeixeBR, 2019).

In intensive fish farming systems, feed represents more than $50 \%$ of operating costs (El-Sayed, 2006), hence, it is necessary to search for alternative feeds to minimize the diet costs. Besides, fishmeal production tends to decline, while demand for this feed resource rises due to an intensification of aquaculture, which makes it increasingly expensive (Olsen \& Hasan, 2012). At the same time, it is ethically questionable to produce aquaculture feed with ingredients common to the human diet and product. Therefore, the use of alternative feeds to mitigate their rising costs needs to be thoroughly researched, since such feeds may contain substances that could impair the productive performance, health, and well-being of fish (Rana et al., 2009).

Glycerol is a viscous liquid material of amber coloration, with $15.66 \mathrm{MJ} \mathrm{kg}^{-1}$ of crude energy that shows an apparent digestible energy of $13.09 \mathrm{MJ} \mathrm{kg}^{-1}$ for Nile tilapia (Meurer et al., 2012), and plays a key role in metabolism as an important structural component of triglycerides and phospholipids, providing energy in glycolytic pathways and in the Krebs cycle. Glycerol can act as an osmoregulator, that is, it allows of the restoring and maintenance of the normal osmotic pressure, and cell activity (Lin, 1977). A higher production of glycerol is anticipated, due to the increasing use of fuel additives. This increase in production will make glycerol available as a cheap raw material.

Glycerol has been proved to be a good alternative feed that can be used as source of energy for omnivorous fish (Li et al., 2010; Neu et al., 2013; Balen et al., 2014; Costa et al., 2015, 2017; Moesch et al., 2016), in the meantime, the use of glycerol in the fattening stage of fish, as Nile tilapia, has not been sufficiently studied yet.

Corn is one of the most commonly used plant-based energetic ingredients in fish diets (Obasa et al., 2013). However, in recent years, the ethanol industry has consumed a large part of produced corn (in the USA it reaches $40 \%$ ), which can lead to the increase of demand and price of corn for animal and human consumption
(Ranum et al., 2014). This way, glycerol could be used to replace corn for Nile tilapia diets at the fattening stage, when large amounts of feed are consumed.

Considering that the final stage leads to higherproduction costs, it is important to investigate glycerol in the diets for Nile tilapia in the fattening stage. Therefore, the study of glycerol in feed for Nile tilapia can provide a greater sustainability of the two production chains, and the biodiesel chain, allowing of the destination of its by-product and the tilapia production chain, since glycerol, as an alternative food, can reduce production costs.

The objective of the present work was to evaluate the use of crude glycerol as an energy source to replace corn in the diets of Nile tilapia in the fattening stage.

\section{Materials and Methods}

This experiment was carried out in the nutrition laboratory of aquatic organisms, and in the laboratory of water quality and limnology, Setor Palotina, in the Universidade Federal do Paraná, in the state of Paraná, Brazil.

Two-hundred GIFT Nile tilapia had their sex reversed by including 17-alpha-methyl-testosterone at $60 \mathrm{ppm}$ in their feed, during the first four weeks. These fish, with $190 \pm 4.5 \mathrm{~g}$ mean individual weight, were distributed in twenty $1,000 \mathrm{~L}$ round fiberglass tanks, in a completely randomized design, with five treatments and four replicates (10 fish per tank); fish were exposed to natural photoperiod (solar light).

The experimental tanks were connected to a filtering system composed of seven 2,000 L circular fiberglass tanks. The first two tanks received water from experimental tanks for decantation; the following two tanks were used for mechanical and biological filtration through pebbles, sand, and screens; two other tanks were used for chemical filtration through macrophytes; the last tank captured the treated water, and returned it to the experimental tanks through an electric pump (1 HP). The tanks were also siphoned twice a day to remove feces, with a subsequent water replacement.

The treatments consisted of the inclusion levels of crude glycerol in the diet at $0,60,120,180$, and $240 \mathrm{~g} \mathrm{~kg}^{-1}$, which corresponds to the replacement of levels of corn in the feed by $0,21,42,63$, and $100 \%$, respectively, based on the digestible energy. The five experimental diets were isoproteic, isoenergetic, 
isophosphoric, and isoaminoacidic for lysine and methionine + cystine. Diet ingredients were previously analyzed in the laboratory of animal nutrition of the Universidade Federal do Paraná for their chemical composition, according to the NRC (2011). These values were considered in the formulation of the experimental diets (Table 1). The feed digestibility values were used as proposed by Boscolo et al. (2002) and Pezzato et al. (2002).

Crude glycerol (BSBIOS Indústria e Comércio de Biodiesel Sul Brasil S/A, Passo Fundo, RS, Brazil) used in the diets was composed of $932.00 \mathrm{~g} \mathrm{~kg}^{-1}$ dry matter, $61.00 \mathrm{~g} \mathrm{~kg}^{-1}$ mineral matter, and $79.60 \mathrm{~g} \mathrm{~kg}^{-1}$ fat.

For feed production, the ingredients were ground in a sieved hammer-mill of $0.7 \mathrm{~mm}$, mixed according to the formulation, and then extruded in an ExMicro extruder (ExTeec Company, Ribeirão Preto, SP, Brazil). Meals were offered three times a day: at 7:00, 12:00, and 17:00 $\mathrm{h}$, until apparent satiation of the animals, so that there were no leftovers.

The physicochemical variables of the experimental water were measured and controlled. Temperature and dissolved oxygen were measured daily at 7:30

Table 1. Ingredients and chemical composition of the experimental diets for Nile tilapia (Oreochromis niloticus) with levels of crude glycerol as a replacement for corn.

\begin{tabular}{|c|c|c|c|c|c|}
\hline \multirow{2}{*}{$\begin{array}{l}\text { Ingredients } \\
\left(\mathrm{g} \mathrm{kg}^{-1}\right)\end{array}$} & \multicolumn{5}{|c|}{ Levels of crude glycerol $\left(\mathrm{g} \mathrm{kg}^{-1}\right.$, wet basis $)$} \\
\hline & 0 & 60 & 120 & 180 & 240 \\
\hline Solvent extracted soybean meal & 615.7 & 628.9 & 642.0 & 655.2 & 678.2 \\
\hline Dried and ground corn & 328.8 & 259.6 & 190.4 & 121.3 & 0.000 \\
\hline Dicalcium phosphate & 30.10 & 30.60 & 31.10 & 31.50 & 31.50 \\
\hline Soybean oil & 13.90 & 9.800 & 5.700 & 1.600 & 12.60 \\
\hline $\operatorname{Premix}^{(1)}$ & 5.000 & 5.000 & 5.000 & 5.000 & 5.000 \\
\hline Salt & 5.000 & 5.000 & 5.000 & 5.000 & 5.000 \\
\hline Limestone & 1.100 & 0.800 & 0.400 & 0.000 & 0.000 \\
\hline $\mathrm{BHT}^{(2)}$ & 0.100 & 0.100 & 0.100 & 0.100 & 0.100 \\
\hline Crude glycerol & 0.000 & 60.00 & 120.0 & 180.0 & 240.0 \\
\hline $\operatorname{Inert}^{(3)}$ & 0.000 & 0.000 & 0.000 & 0.000 & 27.30 \\
\hline \multicolumn{6}{|l|}{ Nutrient ${ }^{(4)}$} \\
\hline Crude protein $\left(\mathrm{g} \mathrm{kg}^{-1}\right)$ & 312.3 & 312.6 & 312.9 & 313.1 & 313.6 \\
\hline Digestible protein $\left(\mathrm{g} \mathrm{kg}^{-1}\right)^{(5)}$ & 280.0 & 280.0 & 280.0 & 280.0 & 280.0 \\
\hline Starch $\left(\mathrm{g} \mathrm{kg}^{-1}\right)$ & 287.9 & 246.6 & 205.3 & 164.0 & 91.50 \\
\hline Dry matter $\left(\mathrm{g} \mathrm{kg}^{-1}\right)$ & 917.1 & 916.8 & 916.4 & 916.1 & 919.3 \\
\hline Mineral matter $\left(\mathrm{g} \mathrm{kg}^{-1}\right)$ & 80.70 & 80.80 & 80.90 & 81.00 & 107.6 \\
\hline Ether extract $\left(\mathrm{g} \mathrm{kg}^{-1}\right)$ & 42.10 & 35.40 & 28.70 & 22.00 & 28.20 \\
\hline Gross energy $\left(\mathrm{MJ} \mathrm{kg}^{-1}\right)$ & 17.05 & 16.94 & 16.82 & 16.71 & 16.51 \\
\hline Digestible energy $\left(\mathrm{MJ} \mathrm{kg}^{-1}\right)^{(5)}$ & 12.56 & 12.56 & 12.56 & 12.56 & 12.56 \\
\hline Crude fiber $\left(\mathrm{g} \mathrm{kg}^{-1}\right)$ & 42.80 & 42.10 & 41.70 & 41.10 & 40.10 \\
\hline Linoleic acid $\left(\mathrm{g} \mathrm{kg}^{-1}\right)$ & 18.20 & 14.80 & 11.30 & 7.900 & 11.70 \\
\hline Lysine total $\left(\mathrm{g} \mathrm{kg}^{-1}\right)^{(6)}$ & 17.90 & 18.10 & 18.30 & 18.50 & 18.80 \\
\hline Calcium $\left(\mathrm{g} \mathrm{kg}^{-1}\right)$ & 10.00 & 10.00 & 10.00 & 10.00 & 10.00 \\
\hline Total phosphorus $\left(\mathrm{g} \mathrm{kg}^{-1}\right)$ & 10.00 & 10.00 & 10.00 & 10.00 & 9.800 \\
\hline Met and cys total $\left(\mathrm{g} \mathrm{kg}^{-1}\right)$ & 9.000 & 8.900 & 8.800 & 8.700 & 8.600 \\
\hline
\end{tabular}

(1)Vitamin and mineral supplement assurance levels per kilogram of product: vitamin A, 1,200,000 IU; vitamin D3, 200,000 IU; vitamin E, 12,000 mg; vitamin K3, 2,400 mg; vitamin B1, 4,800 mg; vitamin B2, 4,800 mg; vitamin B6, 4,000 mg; vitamin B12, 4,800 mg; folic acid, 1,200 mg; calcium pantothenate, 12,000 mg; vitamin C, 48,000 mg; biotin, $48 \mathrm{mg}$; choline, 65,000 mg; niacin, 24,000 mg; Fe, 10,000 mg; Cu, 6,000 mg; Mn, 4,000 mg; Zn, $6,000 \mathrm{mg}$; I, $20 \mathrm{mg}$; Co, $2 \mathrm{mg}$; Se, $20 \mathrm{mg} .{ }^{(2} \mathrm{BHT}$, butyl hydroxide toluene. ${ }^{(3)}$ Corncob. ${ }^{(4)}$ Values analyzed at the animal nutrition laboratory (Universidade Federal do Paraná, Palotina, PR, Brazil) ${ }^{(5)}$ Values calculated by previously conducted digestibility experiments. ${ }^{(6)}$ NRC (2011). 
$\mathrm{h}$ and at 16:30 $\mathrm{h}$, with a dissolved oxygen meter (Lutron DO-5519). $\mathrm{pH}$ was determined daily with a digital counter pHmeter (Tecnopon mPA 210). Total alkalinity and hardness were determined by titration, and ammonia and nitrite, by the colorimetric method according to APHA (2005). Titration and colorimetry measurements were evaluated weekly. The mean values for physicochemical parameters were: temperature, $26.40 \pm 0.05^{\circ} \mathrm{C}$; dissolved oxygen, $4.69 \pm 0.15 \mathrm{mg} \mathrm{L}^{-1}$; $\mathrm{pH}, 7.31 \pm 0.05$; ammonia, $0.64 \pm 0.03 \mathrm{mg} \mathrm{L}^{-1}$; nitrite, $0.07 \pm 0.00 \mathrm{mg} \mathrm{L}^{-1}$; hardness, $50.52 \pm 0.97 \mathrm{mg} \mathrm{L}^{-1} \mathrm{CaCO}_{3}$; alkalinity, $93.49 \pm 2.78 \mathrm{mg} \mathrm{L}^{-1} \mathrm{CaCO}_{3}$.

After 50 days of experimental trial, fish were kept fasting for 24 hours, to empty the gastrointestinal tract. After this period, they were euthanized in a solution of water and clove oil (Taylor \& Roberts, 1999) at 100 $\mathrm{mg} \mathrm{L}^{-1}$ (approved by the Ethics Committee, protocol number 09/2012-CEUA of the Universidade Federal do Paraná). Fish underwent evaluations for their productive performance, out of which five fish per tank were subjected to the analyses for the chemical composition of the fillet, histological analyses of the hepatopancreas and intestine, and visceral fat (removed by dissection, and posteriorly weighed).

The individual measurements of total weight, total length, standard length, length of the head, fish height, and fish width were performed. From these measurements, the performance parameters were calculated for daily weight gain (DWG), specific growth rate (SGR), feed conversion ratio (FCR), carcass yield with or without head, trunk yield, fillet yield and hepatosomatic index (HI).

The DWG was calculated by the following equation: [(final weight - initial weight) / number of days]. The SGR was determined with equation $\{[(\ln$ total final weight - In total initial weight) / (experiment time days)] $\times 100\}$, using a logarithmic transformation. HI was calculated by the equation [(hepatopancreas or liver weight $/$ total final weight $) \times 100]$. Visceral fat $(\%)$ was calculated by the equation [(visceral fat weight $/$ total final weight) $\times 100$ ]. Feed conversion ratio was calculated by dividing the feed consumption by fish weight gain obtained in the period. In order to determine the fillet chemical composition, it was ground until homogeneity was obtained. The amount of ether extract, crude protein, mineral and dry matter was evaluated from this sample, according to methods
960.39, 981.10, 920.153, and 950.46, respectively, proposed by AOAC (2005).

For the histological evaluation, fragments of the hepatopancreas and intestine (proximal part) of five fish per experimental unit were collected, fixed in $10 \%$ formalin for 12 hours, and then preserved in $70 \%$ alcohol. Fragments were then dehydrated in an ascending alcohol series, cleared in xylene and, finally, embedded in paraffin, in order to obtain semiserial histological cuts. Histological cuts of $5 \mu \mathrm{m}$ were obtained with a disposable razor in an automatic microtome (Leica RM-2155), and then stained with hematoxylin-eosin. The photo documentation was captured with a light microscope Zeiss Primo Star, with a 40X objective, using a computerized image system Image Pro Plus - Version 5.2 (Media Cibernética). The morphology of the hepatopancreas was studied by measuring the total area of 20 hepatocytes per animal. The height of the intestinal villi was obtained by measuring 20 villi per fish.

For the hematological evaluation of glucose concentration, three fish per experimental unit were immersed in a solution at $75 \mathrm{mg} \mathrm{L}^{-1}$ clove oil (Taylor \& Roberts, 1999) to be anesthetized. Then, $1 \mathrm{~mL}$ blood was withdrawn per fish, through caudal puncture, with the aid of a disposable syringe. The evaluation was performed at three different moments $(60,90$, and 120 min) after the first feeding $(07: 00 \mathrm{~h})$ in the day prior to euthanasia. Fish used in each moment were marked by cut of the dorsal fin, after blood withdrawal.

The blood samples were refrigerated at $4{ }^{\circ} \mathrm{C}$ with EDTA (10\%), and centrifuged at 1,008 $g$ for $5 \mathrm{~min}$ for plasma separation. Plasma was then used to evaluate the glucose levels. We used the kit Bioliquid (Pinhais, PR, Brazil) for blood glucose, and the readings were performed on an automated spectrophotometer Quick Lab II model (Drake, São Paulo, SP, Brazil).

For the statistical processing, assumptions were tested by performing the normality of the data by the Shapiro-Wilk's method, and the homoscedasticity test (equality of variance), by the Levenne test. Data for performance parameters, chemical composition of the fillet, total hepatocyte area, height of intestinal villi, survival, and hematology were subjected to the analysis of variance, at $5 \%$ probability. In case of statistical differences, the regression analysis and Tukey's test were applied, using the software Statistica 7.0. 


\section{Results and Discussion}

The growth parameters (final weight, DWG, SGR, FCR, survival, total and standard length, width, and height) of Nile tilapia, during the fattening stage, were not affected by the increasing levels of crude glycerol in the diet, as replacement for corn (Table 2). Fillet yield, trunk yield, and carcass yield with or without Nile tilapia head were also not influenced by increasing crude glycerol in diets. The only verified effect of glycerol on the productive performance was the reduction of visceral fat (\%) of fish, whose results fitted a quadratic curve with the increase of crude glycerol in the diet; the optimum level of inclusion was estimated at $164.50 \mathrm{~g} \mathrm{~kg}^{-1}$.

The lack of effects in growth performance results and the decrease of visceral fat show that Nile tilapia, at this stage, has no problems related to the use of crude glycerol, and achieve an adequate growth. In fact, glycerol is absorbed in the intestine, then goes into the bloodstream, and is finally absorbed and metabolized by the liver and other tissues for the synthesis of glucose (via gluconeogenesis), production of energy (via glycolysis and the citric acid cycle), according to Costa et al. (2017).

Other studies also found no variation for the growth parameters of juvenile Nile tilapia, when up to 100 $\mathrm{g} \mathrm{kg}^{-1}$ glycerol (Neu et al., 2013), or $150 \mathrm{~g} \mathrm{~kg}^{-1}$ glycerol (Costa et al., 2015) was added to their diets, namely in the final mean weight and in weight gain. Up to 110 $\mathrm{g} \mathrm{kg}^{-1}$ glycerol can be included in diets of Nile tilapia in the post larvae stage, without affecting the final weight, according to Meurer et al. (2016). However, it is important to note that glycerol effects were observed on Nile tilapia performance in other growth stages. In the juvenile stage, Gonçalves et al. (2015) found an improvement of the Nile tilapia final weight, with 59 $\mathrm{g} \mathrm{kg}^{-1}$ inclusion of glycerol in the diet.

The inclusion levels of crude glycerol in diets of Nile tilapia in the fattening stage did not promote changes of FCR values (Table 2), which can be explained by the fact that the reported values of digestible energy of crude glycerol for Nile tilapia are very close to those of conventional energy sources, such as corn (12.04 to $\left.13.09 \mathrm{MJ} \mathrm{kg}^{-1}\right)$, as reported in other studies (Meurer et al., 2012; Neu et al., 2012a; Gonçalves et al., 2015). Therefore, the substitution of

Table 2. Growth performance, body yield, and visceral fat of Nile tilapia (Oreochromis niloticus) fed crude glycerol (treatment) as a replacement for corn in $\operatorname{diets}^{(1)}$.

\begin{tabular}{|c|c|c|c|c|c|c|c|}
\hline \multirow[t]{2}{*}{ Growth performance variable } & \multicolumn{5}{|c|}{ Treatment $\left(\mathrm{g} \mathrm{kg}^{-1}\right)$} & \multirow{2}{*}{$\begin{array}{l}\text { CV } \\
(\%)\end{array}$} & \multirow{2}{*}{$\begin{array}{l}\text { Anova } \\
\text { p-value }\end{array}$} \\
\hline & 0 & 60 & 120 & 180 & 240 & & \\
\hline Final individual weight $(\mathrm{g})$ & $357 \mathrm{a}$ & $354 a$ & $354 a$ & $348 \mathrm{a}$ & $366 a$ & 1.9 & 0.5496 \\
\hline DWG $\left(\mathrm{g} \mathrm{day}^{-1}\right)$ & $3.41 \mathrm{a}$ & $3.36 \mathrm{a}$ & $3.37 \mathrm{a}$ & $3.23 \mathrm{a}$ & $3.61 \mathrm{a}$ & 4.0 & 0.4977 \\
\hline SGR $\left(\%\right.$ day $\left.^{-1}\right)$ & $1.28 \mathrm{a}$ & $1.27 \mathrm{a}$ & $1.28 \mathrm{a}$ & $1.23 \mathrm{a}$ & $1.35 \mathrm{a}$ & 3.4 & 0.4986 \\
\hline FCR & $1.77 \mathrm{a}$ & $1.75 \mathrm{a}$ & $1.77 \mathrm{a}$ & $1.82 \mathrm{a}$ & $1.64 \mathrm{a}$ & 3.8 & 0.5252 \\
\hline Survival (\%) & $90.0 \mathrm{a}$ & $87.5 \mathrm{a}$ & $92.5 \mathrm{a}$ & $90.0 \mathrm{a}$ & $90.0 \mathrm{a}$ & 2.0 & 0.7998 \\
\hline Total length $(\mathrm{cm})$ & $25.4 \mathrm{a}$ & $25.5 \mathrm{a}$ & $25.3 \mathrm{a}$ & $25.3 \mathrm{a}$ & $25.7 \mathrm{a}$ & 0.6 & 0.5472 \\
\hline Standard length $(\mathrm{cm})$ & $20.6 \mathrm{a}$ & $20.5 \mathrm{a}$ & $20.6 \mathrm{a}$ & $20.4 \mathrm{a}$ & $20.9 \mathrm{a}$ & 0.9 & 0.4175 \\
\hline Width (cm) & $3.69 \mathrm{a}$ & $3.70 \mathrm{a}$ & $3.69 \mathrm{a}$ & $3.70 \mathrm{a}$ & $3.75 \mathrm{a}$ & 0.7 & 0.1891 \\
\hline Height $(\mathrm{cm})$ & $8.62 \mathrm{a}$ & $8.83 \mathrm{a}$ & $8.72 \mathrm{a}$ & $8.74 \mathrm{a}$ & $8.82 \mathrm{a}$ & 0.9 & 0.1988 \\
\hline \multicolumn{8}{|l|}{ Body yield and visceral fat (\%) } \\
\hline Visceral fat index ${ }^{(2)}$ & $2.52 \mathrm{a}$ & $1.39 \mathrm{~b}$ & $1.37 \mathrm{~b}$ & $1.08 \mathrm{~b}$ & $1.29 \mathrm{~b}$ & 35 & 0.0010 \\
\hline Fillet yield & $36.8 \mathrm{a}$ & $37.5 \mathrm{a}$ & $37.7 \mathrm{a}$ & $37.5 \mathrm{a}$ & $38.0 \mathrm{a}$ & 1.1 & 0.2667 \\
\hline Carcass with head yield & $87.0 \mathrm{a}$ & $89.2 \mathrm{a}$ & $89.2 \mathrm{a}$ & $89.1 \mathrm{a}$ & $89.0 \mathrm{a}$ & 1.1 & 0.1874 \\
\hline Carcass without head yield & $66.9 \mathrm{a}$ & $68.5 \mathrm{a}$ & $69.3 \mathrm{a}$ & $68.1 \mathrm{a}$ & $66.7 \mathrm{a}$ & 1.6 & 0.3661 \\
\hline Trunk yield & $48.7 \mathrm{a}$ & $49.8 \mathrm{a}$ & $49.2 \mathrm{a}$ & $47.8 \mathrm{a}$ & $48.6 \mathrm{a}$ & 1.5 & 0.4086 \\
\hline
\end{tabular}

(1)Mean values followed by equal letters, in the lines, do not differ, by Tukey's test, at 5\% probability. DWG, daily weight gain; SGR, specific growth rate; FCR, feed conversion ratio. ${ }^{(2)}$ Quadratic effect: $y=0.00004 \mathrm{x}^{2}-0.0160 \mathrm{x}+2.430 ; \mathrm{R}^{2}=0.920$. 
corn by crude glycerol is feasible and does not affect the efficiency of feed utilization of the Nile tilapia in the fattening stage. Studies with the same species, at different stages, also showed the noneffect of glycerol on the FCR values (Neu et al., 2012b, 2013; Costa et al., 2015; Meurer et al., 2016).

Fish survival was not influenced by the inclusion of crude glycerol in diets (Table 2), which agrees with the results of Li et al. (2010), Neu et al. (2013), Gonçalves et al. (2015), Costa et al. (2015), and Meurer et al. (2016). However, lower survival of Nile tilapia fingerlings fed increasing levels of dietary glycerol was found by Neu et al. (2012b); nonetheless, it should be noted that in this cited research, the mean experimental temperature was $21.4^{\circ} \mathrm{C}$, which is below the level of thermal comfort $\left(25\right.$ to $32^{\circ} \mathrm{C}$ ) for this species (El-Sayed \& Kawanna, 2008), while in the present study the temperature was $26^{\circ} \mathrm{C}$.

Establishing the effect on survival is very important when researching new ingredients, especially by-products which may contain contaminants, such as toxic factors. Methanol residues can be found in crude glycerol, since it is used as a catalyst in biodiesel production. In the present work, the diets were subjected to a process of extrusion, which involves exposing them to high temperatures with subsequent drying, therefore, it is likely that such contaminant may have evaporated, thus causing neither impact nor harm to Nile tilapia in the fattening stage.

The present study found a quadratic dependence of visceral fat on the inclusion levels of crude glycerol in diets (Table 2), which shows that glycerol does not cause any nutritional imbalance, or rather can prevent this by reducing the deposition of fat in the viscera. This result is in disagreement with those presented by Gonçalves et al. (2015) and Neu et al. (2013) for Nile tilapia, who found no significant dependence of similar parameters (liposomatic index and visceral fat weight, respectively) on glycerol inclusion. Still, it is worth noting that these authors used lower levels of inclusion of this ingredient.

Nile tilapia fillet yield was not affected by the inclusion of crude glycerol in the diets (Table 2). Li et al. (2010) found a different result in channel catfish, for which the highest level of inclusion showed the lowest value. Other body yields of Nile tilapia were also not affected by the inclusion of crude glycerol in the diets, in particular, the muscle growth, especially those muscles that make up the fillet, which is the main product of the production chain of Nile tilapia.

In the chemical composition of the fillet, the percentage of ether extract and moisture were influenced by crude glycerol levels, while crude protein and mineral matter were not (Table 3). The inclusion of crude glycerol in diets of Nile tilapia promoted a quadratic fit in the data obtained on the fat parameter of fillet, which showed the lowest value found for inclusion levels of $143.40 \mathrm{~g} \mathrm{~kg}^{-1}$. A quadratic dependence on the level of crude glycerol in the diets was observed in the decrease of ether extract and in the increase of moisture. The same fact was observed by Li et al. (2010), who studied the replacement of corn by crude glycerol in diets for catfish, at $0,50,100,150$, and $200 \mathrm{~g} \mathrm{~kg}^{-1}$ crude glycerol. These authors suggest that the decrease of lipid content can be explained by a difficulty of catfish to metabolize glycerol into lipids.

In the present study, the low amount of crude fat in fillets of Nile tilapia could be explained by the interference of glycerol in the energetic metabolism. Glycerol spares the use and/or breakdown of proteins as energy source; it also affects the lipogenesis, thus slowing this metabolic pathway, as Li et al. (2010) had quoted.

As to the histological analysis of the hepatopancreas, intestine, and visceral fat, replacing corn by crude glycerol in diets for Nile tilapia caused no significant changes in the hepatosomatic index (Table 4), which is in agreement with the results by Neu et al. (2013), Costa et al. (2015), and Gonçalves et al. (2015) for Nile tilapia. No effect was also verified in the evaluated histological parameters. Besides, the morphology of

Table 3. Chemical composition of fillet (dry matter basis) of Nile tilapia (Oreochromis niloticus) fed crude glycerol (treatment) as a replacement for corn in $\operatorname{diets}^{(1)}$.

\begin{tabular}{lccccccc}
\hline Parameter & \multicolumn{9}{c}{ Treatment $\left(\mathrm{g} \mathrm{kg}^{-1}\right)$} & $\begin{array}{c}\mathrm{CV} \\
(\%)\end{array}$ & $\begin{array}{c}\text { Anova } \\
\text { p-value }\end{array}$ \\
\cline { 2 - 6 } & 0 & 60 & 120 & 180 & 240 & & 0.0007 \\
\hline EE $(\%)^{(2)}$ & $1.59 \mathrm{a}$ & $1.76 \mathrm{a}$ & $1.06 \mathrm{~b}$ & $0.98 \mathrm{~b}$ & $1.44 \mathrm{a}$ & 24 & 0.1947 \\
CP $(\%)$ & $21.6 \mathrm{a}$ & $21.5 \mathrm{a}$ & $21.2 \mathrm{a}$ & $21.2 \mathrm{a}$ & $21.3 \mathrm{a}$ & 1.0 & 0.1947 \\
Moisture (\%) & $76.1 \mathrm{~b}$ & $77.0 \mathrm{a}$ & $77.4 \mathrm{a}$ & $76.9 \mathrm{a}$ & $76.2 \mathrm{~b}$ & 0.7 & 0.0393 \\
MM $(\%)$ & 1.27 & 1.25 & 1.27 & 1.18 & 1.25 & 3.0 & 0.1206 \\
\hline
\end{tabular}

${ }^{(1)}$ Mean values followed by equal letters, in the lines, do not differ by Tukey's test, at 5\% probability. ${ }^{(2)}$ Quadratic effect: $\mathrm{y}=0.00002 \mathrm{x}^{2}-0.083 \mathrm{x}$ $+1.697 ; \mathrm{R}^{2}=0.725 .{ }^{(3)}$ Quadratic effect: $\mathrm{y}=0.00007 \mathrm{x}^{2}-0.0192 \mathrm{x}+76.12$; $\mathrm{R}^{2}=0.981$. EE, ether extract; $\mathrm{CP}$, crude protein; and MM, mineral matter. 
intestinal villi, in the proximal segment of the intestine of Nile tilapia, shows a normal organization (Figure 1).

The mucosa layer showed a simple columnar epithelium, formed by enterocytes and normal goblet cells (mucus). Nevertheless, the intestinal villi showed a pemphigus aspect and height irregularities, and did not reveal the presence of intestinal crypts (Figure 1). In the morphological analysis, the hepatocytes displayed round shapes arranged in a slightly cordonal organization, around sinusoidal capillaries. The hepatocytes were characterized by their central core, with high basophilia and vacuolated cytoplasm.

The characteristics described for the intestinal villi and for the morphology of the hepatopancreas in Nile tilapia supplemented with crude glycerol are within the normal range, according to Gargiulo et al. (1998) and Vicentini et al. (2005), respectively. Since there were no significant differences in the morphometric analysis of the intestinal villi and hepatocytes, it appears that crude glycerol did not affect these structures.

Fish hepatocytes are considered the first target of toxins, which makes the liver a biomarker organ of environmental pollution (Zelikoff, 1998). Thus, it can be inferred that the hepatopancreas and intestine of tilapia fed different crude glycerol levels were not affected by the presence of some impurities, or toxins such as methanol, or some metals, which even in minute quantities could interfere with fish metabolism.

At all sampling times, blood glucose responded linearly to glycerol inclusion levels (Table 5). Fish glycemia showed a linear increase with the inclusion levels of crude glycerol, $60 \mathrm{~min}$ after the first feeding. However, 90 min after the first feeding, there was an increase of blood glucose levels, in comparison with the previous sampling time; however, a decreasing linear

Table 4. Hepatosomatic index (HSI), area of hepatocytes $(\mathrm{AH})$, and intestinal villi height (IVH) of Nile tilapia (Oreochromis niloticus) fed crude glycerol (treatment) as a replacement for corn in $\operatorname{diets}^{(1)}$.

\begin{tabular}{|c|c|c|c|c|c|c|c|}
\hline \multirow[t]{2}{*}{ Parameter } & \multicolumn{5}{|c|}{ Treatment $\left(\mathrm{g} \mathrm{kg}^{-1}\right)$} & \multirow{2}{*}{$\begin{array}{l}\mathrm{CV} \\
(\%)\end{array}$} & \multirow{2}{*}{$\begin{array}{c}\text { Anova } \\
\text { p-value }\end{array}$} \\
\hline & 0 & 6 & 12 & 18 & 24 & & \\
\hline HSI & $1.44 \mathrm{a}$ & $1.37 \mathrm{a}$ & $1.48 \mathrm{a}$ & $1.31 \mathrm{a}$ & $1.56 \mathrm{a}$ & 6.76 & \\
\hline $\mathrm{AH}(\mu \mathrm{m})$ & $273 a$ & $250 \mathrm{a}$ & $252 \mathrm{a}$ & $254 \mathrm{a}$ & $257 \mathrm{a}$ & 3.58 & 0.4257 \\
\hline $\mathrm{IVH}(\mu \mathrm{m})$ & $599 \mathrm{a}$ & $595 \mathrm{a}$ & $566 \mathrm{a}$ & $577 \mathrm{a}$ & $578 \mathrm{a}$ & 2.38 & 0.5345 \\
\hline
\end{tabular}

(1) Mean values followed by equal letters, in the lines, do not differ by Tukey's test, at $5 \%$ probability. response occurred with the inclusion levels of crude glycerol. At $120 \mathrm{~min}$ after the first feeding, a linear decrease of blood glucose occurred with the inclusion levels of crude glycerol in the diets; at this sampling time, blood glucose values decreased, in comparison to the previous sampling time $(90 \mathrm{~min})$. Also, the two highest levels of crude glycerol inclusion (180 and 240
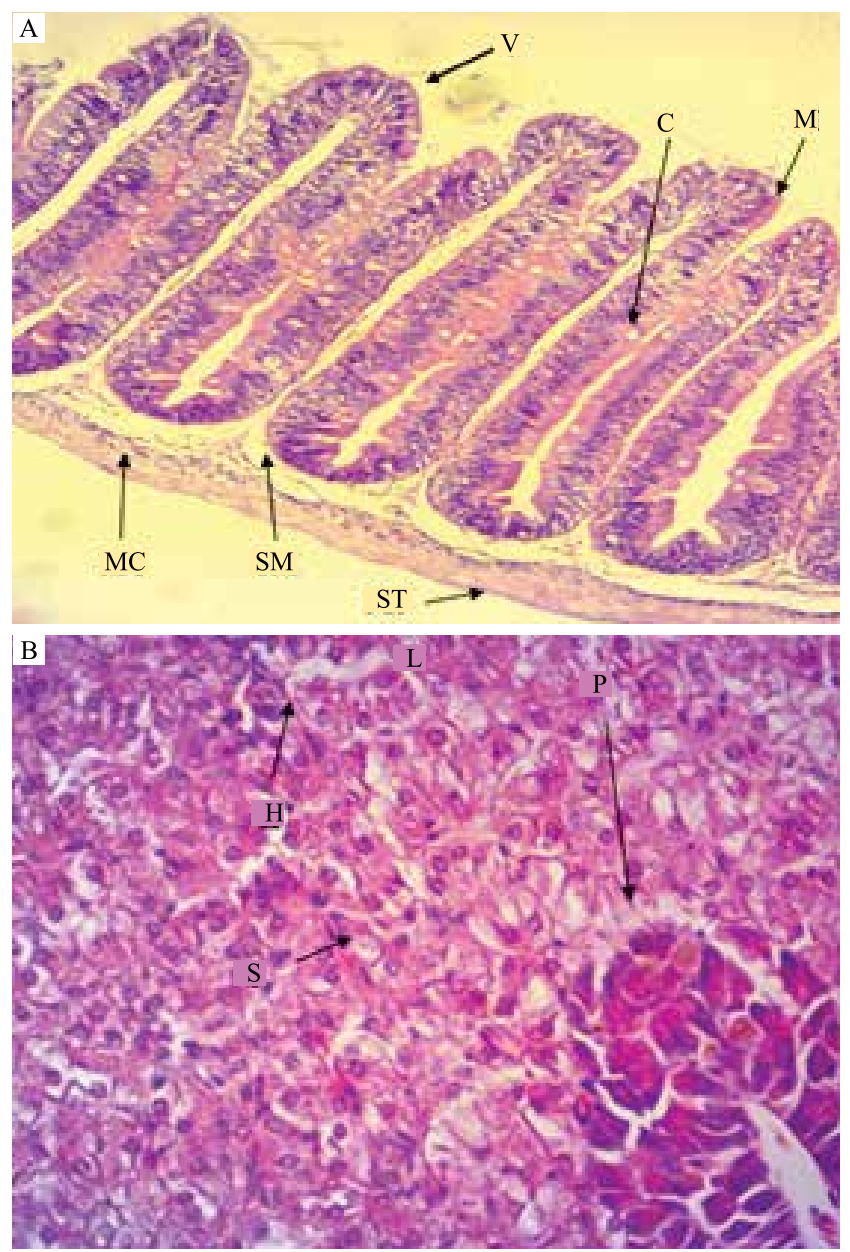

Figure 1. A, photomicrograph of the proximal segment of Nile tilapia (Oreochromis niloticus) fed crude glycerol, at different levels of inclusion: $\mathrm{V}$, the intestinal villi; $\mathrm{M}$, mucosal epithelium; SM, tunic submucosa; MC, muscular tunic; ST, serous tunic; $\mathrm{C}$, goblet cell. Stained with hematoxylin and eosin (HE), 10X magnification. B, photomicrograph of histological aspects of Nile tilapia hepatocytes fed crude glycerol at different levels of inclusion, as a replacement for corn in diets: $\mathrm{H}$, disposition of hepatocytes, surrounded by capillary sinusoids (S); P, intrahepatic exocrine pancreatic tissue; L, liver. Stained with HE, 40X magnification. 
$\mathrm{g} \mathrm{kg}^{-1}$ ) showed similar blood concentrations to those of the first sampling time (60 min.).

The inclusion of glycerol and, consequently, reduction of corn in the diets resulted in lower levels of blood glucose in Nile tilapia (Table 5). Comparing the results obtained at different sampling times after the first feeding $(60,90$, and $120 \mathrm{~min})$, it can be observed that blood glucose in fish fed the highest levels of glycerol showed no significant peak. The peak value of plasma glucose concentration was observed in the control treatment $(0 \%$ glycerol) that reached $81.0 \mathrm{mg}$ $\mathrm{dL}^{-1}$ at 90 min after feeding. Moreover, the highest value was only $64.6 \mathrm{mg} \mathrm{dL}^{-1}$ at $240 \mathrm{~g} \mathrm{~kg}^{-1}$ inclusion. Moreira et al. (2011) determined the basal blood glucose level at $60 \mathrm{mg} \mathrm{dL}^{-1}$, in a control group of five Nile tilapia at the growth stage, which were not exposed to anesthetic agents, and were fasting.

In the treatments with 180 and $240 \mathrm{~g} \mathrm{~kg}^{-1}$ of glycerol inclusion, the glucose level in Nile tilapia was quickly reestablished to the baseline $\left(\sim 40 \mathrm{mg} \mathrm{dL}^{-1}\right)$, after a small peak of plasma glucose $90 \mathrm{~min}$ after the first feed (Table 5). Values of blood glucose were reported as close to $35.8 \mathrm{mg} \mathrm{dL}^{-1}$, in tilapia of similar size ( $420 \mathrm{~g})$ captured in a fee-fishing farm, fed commercial extruded feed, and anaesthetized in solutions containing benzocaine in the ratio $1 \mathrm{~g} 10 \mathrm{~L}^{-1}$ of water (Azevedo et al., 2006).

After the peak at $90 \mathrm{~min}$, blood glucose level in fish fed the control diet $\left(0 \mathrm{~g} \mathrm{~kg}^{-1}\right.$ glycerol, that is, only corn starch) took longer to reestablish the baseline (Table 5). Nile tilapia uses starch in an efficient manner, in comparison to other fish species. However, Wright et al. (1999) stated that despite this, the intake of high levels of starch results in high-blood glucose levels, and the return to baseline levels are much

Table 5. Blood glucose concentrations $\left(\mathrm{mg} \mathrm{dL}^{-1}\right)$ in Nile tilapia (Oreochromis niloticus) fed crude glycerol (treatment) as a replacement for corn in $\operatorname{diets}^{(1)}$.

\begin{tabular}{|c|c|c|c|c|c|c|c|}
\hline \multirow{2}{*}{$\begin{array}{l}\text { Sampling time } \\
\text { after feeding }\end{array}$} & \multicolumn{5}{|c|}{ Treatment $\left(\mathrm{g} \mathrm{kg}^{-1}\right)$} & \multirow{2}{*}{$\begin{array}{l}\mathrm{CV} \\
(\%)\end{array}$} & \multirow{2}{*}{$\begin{array}{l}\text { Anova } \\
\text { p-value }\end{array}$} \\
\hline & 0 & 60 & 120 & 180 & 240 & & \\
\hline & & 50.00 & 11.00 & $.3 b$ & $47.0 \mathrm{~b}$ & & \\
\hline & b & $72.6 \mathrm{a}$ & $65.0 \mathrm{a}$ & $63.6 \mathrm{a}$ & $64.6 \mathrm{a}$ & 7.90 & 0.000 \\
\hline $120 \min ^{(4)}$ & $57.0 \mathrm{ab}$ & $57.0 \mathrm{ab}$ & $52.0 \mathrm{ab}$ & $47.6 \mathrm{~b}$ & $45.6 \mathrm{~b}$ & & 0.000 \\
\hline
\end{tabular}

(1)Mean values followed by equal letters do not differ by Tukey's test, at $5 \%$ probability. ${ }^{(2)} \mathrm{y}=0.0347 \mathrm{x}+30.69 ; \mathrm{R}^{2}=0.9294 .{ }^{(3)} \mathrm{y}=-0,0497 \mathrm{x}+85.89$; $\mathrm{R}^{2}=0.9469 .{ }^{(4)} \mathrm{y}=-0,034 \mathrm{x}+61.8 ; \mathrm{R}^{2}=0.9383$. slower than when fish are nourished with other feeds. This was confirmed in the present study.

Glycerol does not lead to similar visceral fat depots as corn does. In fact, the glycerol inclusion in the diet of Nile tilapia did not result in high-blood glucose values; additionally, no high-blood glucose peaks were observed either, as glycerol is used efficiently and rapidly as an energy source, and tilapia does not metabolize it into fat (visceral fat and fillet fat), an effect that was observed in the control treatment.

Although the lowest values of visceral and fillet fat were obtained with the inclusion of $164.5 \mathrm{~g} \mathrm{~kg}^{-1}$ and $143.4 \mathrm{~g} \mathrm{~kg}^{-1}$ crude glycerol in the diet, respectively, it can be inferred that glycerol can totally replace corn as an energy source, without negatively affecting growth and metabolism of Nile tilapia in the fattening stage. In addition to the scientific importance, these results represent a concomitant economic importance because, at this stage of Nile tilapia high growth with consequent higher expenses with feed, it is possible to use an increasingly available ingredient, besides mobilizing the sustainability of the productive chain.

In order to have glycerol as a viable, alternative feed in the aquaculture industry, it is necessary to regulate its production, and standardize its quality, to ensure feed safety, animal welfare, and aquaculture productivity.

\section{Conclusion}

Crude glycerol can be used in diets for Nile tilapia in the fattening stage, as a replacement for corn, without adversely affecting fish metabolism, productive performance, or survival.

\section{Acknowledgments}

To Conselho Nacional de Desenvolvimento Científico e Tecnológico (CNPq), for financial support (Grant no. 471801/2011-9).

\section{References}

AOAC. Association of Official Analytical Chemists. Official Methods of Analysis of AOAC International. $18^{\text {th }}$ ed. Gaithersburg: AOAC International, 2005. Official Methods 920.153, 950.46, 960.39, and 981.10. 
APHA. American Public Health Association. Standard methods for the examination of water $\&$ wastewater. $21^{\text {st }}$ ed. Washington, 2005 .

AZEVEDO, T.M.P. de; MARTINS, M.L.; YAMASHITA, M.M.; FRANCISCO, C.J. Hematologia de Oreochromis niloticus: comparação entre peixes mantidos em piscicultura consorciada com suínos e em pesque-pague no vale do rio Tijucas, Santa Catarina, Brasil. Boletim do Instituto de Pesca, v.32, p.41-49, 2006.

BALEN, R.E.; TETU, P.N.; BOMBARDELLI, R.A.; POZZA, P.C.; MEURER, F. Digestible energy of crude glycerol for pacu and silver catfish. Ciência Rural, v.44, p.1448-1451, 2014. DOI: https://doi.org/10.1590/0103-8478cr20131426.

BOSCOLO, W.R.; HAYASHI, C.; MEURER, F. Digestibilidade aparente da energia e nutrientes de alimentos convencionais e alternativos para a tilápia do nilo (Oreochromis niloticus, L.). Revista Brasileira de Zootecnia, v.31, p.539-545, 2002. DOI: https://doi.org/10.1590/S1516-35982002000300001.

COSTA, D.V. da; DIAS, J.; COLEN, R.; ROSA, P.V.; ENGROLA, S. Partition and metabolic fate of dietary glycerol in muscles and liver of juvenile tilapia. Archives of Animal Nutrition, v.71, p.165174, 2017. DOI: https://doi.org/10.1080/1745039X.2017.1281579.

COSTA, D.V. da; PAULINO, R.R.; OKAMURA, D.; OLIVEIRA, M.M. de; ROSA, P.V. e. Growth and energy metabolism of Nile tilapia juveniles fed glycerol. Pesquisa Agropecuária Brasileira, v.50, p.347-354, 2015. DOI: https://doi.org/10.1590/ S0100-204X2015000500001.

EL-SAYED, A.-F.M. Tilapia culture. London: CABI, 2006. 277p.

EL-SAYED, A.-F.M.; KAWANNA, M. Optimum water temperature boosts the growth performance of Nile tilapia (Oreochromis niloticus) fry reared in a recycling system. Aquaculture Research, v.39, p.670-672, 2008. DOI: https://doi. org/10.1111/j.1365-2109.2008.01915.x.

FAO. The state of world fisheries and aquaculture 2018: meeting the sustainable development goals. Rome: FAO, 2018. 227p.

GARGiUlo, A.M.; CECCARELli, P.; DALl'AGLIO, C.; PEDINI, V. Histology and ultrastructure of the gut of the tilapia (Tilapia spp.), a hybrid teleost. Anatomia, Histologia, Embryologia, v.27, p.89-94, 1998. DOI: https://doi. org/10.1111/j.1439-0264.1998.tb00162.x.

GONÇALVES, L.U.; CEROZI, B. da S.; SILVA, T.S.C.; ZANON, R.B.; CYRINO, J.E.P. Crude glycerin as dietary energy source for Nile tilapia. Aquaculture, v.437, p.230-234, 2015. DOI: https:// doi.org/10.1016/j.aquaculture.2014.12.004.

LI, M.H.; MINCHEW, C.D.; OBERLE, D.F.; ROBINSON, E.H. Evaluation of glycerol from biodiesel production as a feed ingredient for channel catfish, Ictalurus punctatus. Journal of the World Aquaculture Society, v.41, p.130-136, 2010. DOI: https:// doi.org/10.1111/j.1749-7345.2009.00320.x.

LIN, E.C.C. Glycerol utilization and its regulation in mammals. Annual Review of Biochemistry, v.46, p.765-795, 1977. DOI: https://doi.org/10.1146/annurev.bi.46.070177.004001.

MEURER, F.; FRANZEN, A.; PIOVESAN, P.; ROSSATO, K.A.; SANTOS, L.D. dos. Apparent energy digestibility of glycerol from biodiesel production for Nile tilapia (Oreochromis niloticus, Linnaeus 1758). Aquaculture Research, v.43, p.1734-1737, 2012. DOI: https://doi.org/10.1111/j.1365-2109.2011.02974.x.

MEURER, F.; TOVO NETO, A.; SILVA, L.C.R. da; CAGOL, L.; THEISEN, M.T.; SANTOS, L.D. dos. Crude glycerol in diets for Nile tilapia sex reversal (Oreochromis niloticus, Linnaeus 1758). Aquaculture Research, v.47, p.2682-2685, 2016. DOI: https://doi. org/10.1111/are.12714.

MOESCH, A.; MEURER, F.; ZADINELO, I.V.; CARNEIRO, W.F.; SILVA, L.C.R. da; SANTOS, L.D. dos. Growth, body composition and hepatopancreas morphology of Nile tilapia fingerlings fed crude glycerol as a replacement for maize in diets. Animal Feed Science and Technology, v.219, p.122-131, 2016. DOI: https://doi.org/10.1016/j.anifeedsci.2016.05.009.

MOREIRA, A.G.L.; TEIXEIRA, E.G.; MOREIRA, R.L.; FARIAS, W.R.L. Glicose plasmática em juvenis de tilápia do Nilo anestesiados com óleo de cravo. Revista Brasileira de Saúde e Produção Animal, v.12, p.794-804, 2011.

NEU, D.H.; FURUYA, W.M.; BOSCOLO, W.R.; BUENO, G.W.; POTRICH, F.R.; FEIDEN, A. Energia digestível de diferentes fontes de glicerol para a tilápia-do-nilo (Oreochromis niloticus). Revista Brasileira de Ciências Agrárias, v.7, p.174-179, 2012a. DOI: https://doi.org/10.5039/agraria.v7ila1501.

NEU, D.H.; FURUYA, W.M.; BOSCOLO, W.R.; POTRICH, F.R.; LUI, T.A.; FEIDEN, A. Glycerol inclusion in the diet of Nile tilapia (Oreochromis niloticus) juveniles. Aquaculture Nutrition, v.19, p.211-217, 2013. DOI: https://doi.org/10.1111/ j.1365-2095.2012.00968.x.

NEU, D.H.; FURUYA, W.M.; YAMASHIRO, D.; BITTENCOURT, F.; MORO, E.B.; FERNANDES, D.R.A.; BOSCOLO, W.R.; FEIDEN, A. Glicerol na dieta de alevinos de tilápia do nilo (Oreochromis niloticus). Revista Agrarian, v.5, p.288-294, 2012b.

NRC. National Research Council. Nutrient requirements of fish and shrimp. Washington: The National Academies Press, 2011. 376p. DOI: https://doi.org/10.17226/13039.

OBASA, S.O.; ALATISE, S.P.; OMONIYI, I.T.; ALEGBELEYE, W.O.; GEORGE, F.A. Evaluation of fermented mango (Mangifera indica) seed meal in the practical diet of Nile tilapia, (Oreochromis niloticus) fingerlings. Croatian Journal of Fisheries, v.71, p.116123, 2013. DOI: https://doi.org/10.14798/71.3.660.

OLSEN, R.L.; HASAN, M.R. A limited supply of fishmeal: impact on future increases in global aquaculture production. Trends in Food Science \& Technology, v.27, p.120-128, 2012. DOI: https://doi.org/10.1016/j.tifs.2012.06.003.

PEIXEBR. Anuário PeixeBR da Piscicultura 2019. São Paulo, 2019. 148p.

PEZZATO, L.E.; MIRANDA, E.C. de; BARROS, M.M.; PINTO, L.G.Q.; FURUYA, W.M.; PEZZATO, A.C. Digestibilidade aparente de ingredientes pela tilápia do Nilo (Oreochromis niloticus). Revista Brasileira de Zootecnia, v.31, p.1595-1604, 2002. DOI: https://doi.org/10.1590/S1516-35982002000700001.

RANA, K.J.; SIRIWARDENA, S.; HASAN, M.R. Impact of rising feed ingredient prices on aquafeeds and aquaculture 
production. Rome: FAO, 2009. 63p. (FAO. Fisheries and aquaculture technical paper, 541).

RANUM, P.; PEÑA-ROSAS, J.P.; GARCIA-CASAL, M.N. Global maize production, utilization, and consumption. Annals of the New York Academy of Sciences, v.1312, p.105-112, 2014. DOI: https://doi.org/10.1111/nyas.12396.

TAYLOR, P.W.; ROBERTS, S.D. Clove oil: an alternative anaesthetic for aquaculture. North American Journal of Aquaculture, v.61, p.150-155, 1999. DOI: https://doi. org/10.1577/1548-8454(1999)061<0150:COAAAF>2.0.CO;2.

VICENTINI, C.A.; FRANCESCHINI-VICENTINI, I.B.; BOMBONATO, M.T.S.; BERTOLUCCI, B.; LIMA, S.G.;
SANTOS, A.S. Morphological study of the liver in the teleost Oreochromis niloticus. International Journal of Morphology, v.23, p.211-216, 2005. DOI: https://doi.org/10.4067/S071795022005000300003 .

WRIGHT, P.M.; MCCORMICK, B.; SHERMAN, W.S.; MCMAHAN, G.C. The role of human resource practices in petro-chemical refinery performance. International Journal of Human Resource Management, v.10, p.551-571, 1999. DOI: https://doi.org/10.1080/095851999340260.

ZELIKOFF, J.T. Biomarkers of immunotoxicity in fish and other non-mammalian sentinel species: predictive value for mammals? Toxicology, v.129, p.63-71, 1998. DOI: https://doi.org/10.1016/ S0300-483X(98)00064-X. 